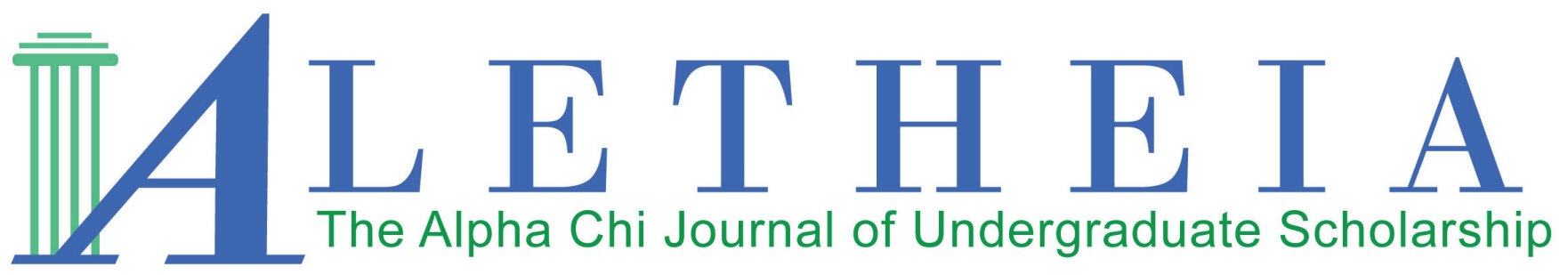

Volume 1 | Issue 2 | 2016

\title{
A Defense of Genesis 3:8 as a Storm Theophany
}

\author{
Christopher Chandler \\ Evangel University \\ Missouri Rho Chapter
}

Vol. 1(2), 2016

Article Title: A Defense of Genesis 3:8 as a Storm Theophany

DOI: $10.21081 / \mathrm{ax} 0065$

ISSN: 2381-800X

Key Words: Genesis, storm-theophany, creation, Hebrew

This work is licensed under a Creative Commons Attribution 4.0 International License.

Author contact information is available from the Editor at editor@alphachihonor.org.

\section{Aletheia-The Alpha Chi Journal of Undergraduate Scholarship}

- This publication is an online, peer-reviewed, interdisciplinary undergraduate journal, whose mission is to promote high quality research and scholarship among undergraduates by showcasing exemplary work.

- Submissions can be in any basic or applied field of study, including the physical and life sciences, the social sciences, the humanities, education, engineering, and the arts.

- Publication in Aletheia will recognize students who excel academically and foster mentor/mentee relationships between faculty and students.

- In keeping with the strong tradition of student involvement in all levels of Alpha Chi, the journal will also provide a forum for students to become actively involved in the writing, peer review, and publication process.

- More information and instructions for authors is available under the publications tab at www.AlphaChiHonor.org. Questions to the editor may be directed to editor@alphachihonor.org.

\footnotetext{
Alpha Chi is a national college honor society that admits students from all academic disciplines, with membership limited to the top 10 percent of an institution's juniors, seniors, and graduate students. Invitation to membership comes only through an institutional chapter. A college seeking a chapter must grant baccalaureate degrees and be regionally accredited. Some 300 chapters, located in almost every state, induct approximately 12,000 members annually. Alpha Chi members have been "making scholarship effective for good" since 1922.
} 


\title{
A Defense of Genesis 3:8 as a Storm Theophany
}

\author{
Christopher Chandler
}

\author{
Evangel University \\ Missouri Rho Chapter
}

\begin{abstract}
The key phrase of Genesis 3:8 "cool of the day" (leruah hayyom) has been recently evaluated in light of Akkadian cognates to the Hebrew and a new translation proposed. The critiques of this new translation are evaluated in this article, which concludes that the new translation has more grammatical support than the traditional reading which is problematic on a number of fronts.
\end{abstract}

Key words: Genesis, storm-theophany, creation, Hebrew

Some passages of the Bible hold an elevated status in the hearts and minds of its readers. The sentimental nature of these passages is often tied to a particular word choice found in the reader's favorite translation. Often, the specific language makes its way into their Christian consciousness, and to change it would be to change an intimate part of that consciousness. For example, even though translators have long known that the story of Jesus staying at an "inn" is a mistranslation, the majority of translations continue to keep the traditional rendering of Luke 2:7. Readers feel a sentimental attachment to the story of a young Jesus being turned away from the inn. After all, what would a Christmas play be without a rude innkeeper?

Many stories in Genesis have become iconic for how Jews and Christians understand the nature of God and humanity. The fall of humanity provides a paradigm for understanding the rest of Scripture, so the translation of these passages has not been taken lightly. One of these iconic passages is Genesis 3:8-13 - the section directly following Adam's and Eve's eating of the forbidden fruit and where God is described as walking in the garden in the "cool of the day" or during an "eve-

${ }^{1}$ These translations include: ESV, KJV, NASB, NIV. ning breeze." 2 The traditional translation, "in the cool of the day," became commonplace in the 16th century. The expression is rendered as such in the Great Bible (1540), the Bishop's Bible (1558), the Geneva Bible (1560) and most notably the King James Version (1611). John Milton's epic Paradise Lost makes use of the language as well when he writes:

From noon, the gentle airs, due at their hour / To fan the earth now walked, and under in The evening cool; when he, from wrath more cool / Came the mild Judge, and the Intercessor both / To sentence Man: The voice of God they heard / Now walking in the garden, by softwinds ${ }^{3}$

The idea of YHWH taking a stroll during the cool part of the day has become widely accepted as illustrating the unique relationship of God and humanity - they were in close proximity and communicated with one another in a much more intimate way than later humans. However, the Hebrew text in this passage is not straightforward in its meaning. The phrase "in the wind of the day" (leruah hayyom) does not occur in any other part of

${ }^{2}$ These translations include: HCSB, NRSV, CEV.

3 John Milton, Paradise Lose, Book X (New York: Barnes and Nobel Books, 2004), 309. 
the Hebrew Scripture. ${ }^{4}$ Several of the words in the passage can be translated in different ways depending on the context: ruah can mean spirit, wind, or breeze; qol has a wide range of options referring to different types of sound (voice, crashing, thunder, etc.); and though yom typically refers to a "day," there is also a connection to the Akkadian cognate $u m u$, which can be translated both and "day" and "storm." While yom is almost exclusively translated as "day," Jeffery Niehaus has shown several potential verses that could be better understood with yom taking on the Akkadian meaning "storm" (Isa 28:7, Zeph 2:2, Song of Songs 2:17 and Gen 3:8). The final word with a significant semantic domain is $h l k$, which occurs here as a hithpael participle and is usually translated as "walking" or "walking about." However, other passages use $h l k$ to reference iterative movement of some sort.

On this basis Jeffery Niehaus proposes a different rendering of Genesis 3:8, as follows:

"Then the man and his wife heard the thunder (qol) of Yahweh God as he was going back and forth $(h l k)$ in the garden in the wind (ruah) of the storm (yom) and they hid from Yahweh God among the trees of the garden."

\begin{tabular}{|c|c|c|}
\hline Hebrew & \begin{tabular}{|l|} 
Traditional \\
Translation \\
\end{tabular} & $\begin{array}{l}\text { Proposed } \\
\text { Alternative }\end{array}$ \\
\hline קוֹ (qol) & Sound & Thunder \\
\hline 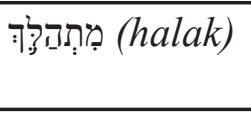 & Walking & $\begin{array}{l}\text { Going back and } \\
\text { forth }\end{array}$ \\
\hline $\begin{array}{l}\text { ?רִרוּח הַיחוֹם } \\
\text { (ruah yom) }\end{array}$ & Cool of the day & $\begin{array}{l}\text { Wind of the } \\
\text { Storm }\end{array}$ \\
\hline
\end{tabular}

4 Umberto Cassuto, A Commentary of the Book of Genesis: Part 1 From Adam to Noah Genesis I-VI 8 (Jerusalem: Magnes Press, 1989), 152.

${ }^{5}$ J.J. Niehaus, "In the Wind of the Storm: Another Look at Genesis III 8" VT 44 (1994), 264. "The Ludwig Koehler and Walter Baumgartner lexicon, on the basis of the Akkadian has noted this second yom, 'wind, sturm,' in the Old Testament." Niehaus offers the example of Zeph. 2:2 to see how yom could help offer a better translation if it meant "storm."

${ }^{6}$ Niehaus, "Wind of the Storm," 265.
Immediately the scene takes on a different mood and message. God is not strolling in the garden during a cool part of the day, but instead comes in a powerful storm theophany. Adding to this idea, Walton shows that the only other time the words ruah and qol do occur together, "is in the context of a storm (Jeremiah 10:13, 51:16) as a reference to "wind' and 'thunder' respectively."

\section{Response to Critiques of the Proposed Translation}

The biggest critic of Niehaus's translation is Christopher Grundke, who begins by arguing that the translation "in the cool of the day" is not a mere guess, but has a text-critical history going back to the Masoretes and is attested to by even earlier Greek translations. ${ }^{8}$ While it is true that the Greek texts seem to understand Genesis 3:8 in a traditional sense, Grundke's point does not address Niehaus's argument regarding how this new translation was overlooked for so many years - the Greek translators and the Masoretes didn't understand how the terms were being used, as they are contingent upon the Akkadian cognate. Multiple words in the verse have a semantic domain that is contingent upon other phrases. The possibility of seeing the passage as a storm theophany rests upon how the translators understand yom. Umberto Cassuto shows that even early Rabbinic expositions of the text were unable to come together with an agreed upon understanding. ${ }^{9}$ So, while the majority of translators and expositors have had a general understanding of the phrase representing some time of day, there has yet to arise one definitive understanding. The translation "cool of the day" or "evening breeze" is certainly interpretive from the literal translation "wind of the day." 10

Regardless of tradition, there is still no answer for this passage's lack of linguistic support. Cassuto shows that "ruah hayom" cannot possibly indicate a wind blow

\footnotetext{
7 John Walton, Genesis: The NIV Application Commentary (Grand Rapids: Zondervan, 2001), 224.

${ }^{8}$ Christopher Grundke, A Tempest in a Teapot? Genesis III 8 Again, VV 51,4 (2001): 548.

${ }^{9}$ Cassuto, Genesis, 152-153.

${ }^{10}$ I was unable to find a single lexicon that listed "cool" as a possible translation for ruah.
} 
ing at a specific time of the day." 11 If this meaning had ליעת רוּה היוֹט (lit. "at the time of the wind of the day") or its equivalent. That is, for example, how Genesis 8:11 reads when speaking of a specific time of day:

"The dove came to him toward evening" (Gen 8:11

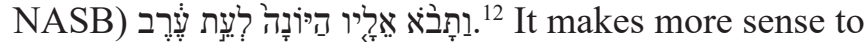
understand ruah hayom as an Akkadian expression that survived in the creation story of the people of Israel. ${ }^{13}$ Another word with possible Akkadian connections in $h l k$. There are instances of the hithpael form being used in storm theophany accounts such as Ezekiel 1:13 and Psalm 77:16-18, as well as in the judgment narrative of Ezekiel 6:7. In these passages hlk connotes iterative movement (i.e. moving all around). Hlk is a common word that occurs in most Semitic languages, but here in Genesis 3:8 it is often used to defend the anthropomorphic interpretation of YHWH strolling in the garden. ${ }^{14}$ Waltke and O'Connor offer interesting insight into the hithpael form of $h l k$, saying that it "presents special problems" and suggesting that the hithpael form of $h l k$ is an "Akkadianism' borrowed into Hebrew." 15 If this is true, then two of the key words in the verse have an Akkadian connection. That is to say, the likelihood of yom being an Akkadian cognate is increased by the presence of $h l k$ as a hithpael. A final option is that yom could also be functioning as a pun primarily meaning "storm" but also referring back to YHWH's statement, "in the day that you eat of it you will surely die" (Genesis 2:17). This interpretation would help explain some of the linguistic awkwardness of the proposed reading.

The last major critique Grundke offers is that Genesis 3:8 does not have the classic elements of a storm theophany. The terms/themes he lists as being absent

\footnotetext{
${ }^{11}$ Cassuto, Genesis, 153.

${ }^{12}$ Other examples include Genesis 24.11, Isa. 17:14, and Zech 14:7.
}

13 Yom could also be functioning as a pun mean primarily meaning storm, but also referring back to YHWH's statement, "in the day that you eat of it you will surely die (Genesis 2:17)." This would help explain some of the linguistic awkwardness of the proposed reading.

${ }^{14}$ Ernst Jenni and Claus Westermann, “hlk,” TLOT 365.

${ }^{15}$ Bruce Waltke and M. O'Connor, An Introduction to Biblical Hebrew Syntax, (Winona Lake, Indiana: Eisenbrauns, 1990), 429. They also note Thomas O. Lambdin who cites "hlk as the only example of the iterative use of the Hithpael; see Introduction to Biblical Hebrew (New York: Scribner, 1971) 250." are clouds, fire, and lightening. ${ }^{16}$ He calls Genesis 3:8 the "most muted and understated storm imaginable." While it is true that the storm theophany here is not as pronounced as future ones, it undoubtedly has enough similar characteristics to be grouped with them. The storm-theophany is not an uncommon occurrence in the Hebrew Scriptures. ${ }^{18}$ Most memorably, YHWH appears in thunder and lightning at the theophany of Mount Sinai. The storm theme is not simply happenstance; J.L. McKenzie argues that "The one natural phenomenon with which YHWH is most frequently associated is the storm...the connection between YHWH and the storm is too common to be merely coincidental." 19 However, contrary to Grundke's implied expectation, not every storm theophany includes all or even a majority of these themes. The theophany at Mount Sinai sets a paradigm for theophanies after it. As such, it does include almost all the phrases Grundke mentions. M.F. Rooker points out that the main emphasis of the storm theophany is that it involves "natural forces that often terrify people." ${ }^{20}$ One major theme of storm theophanies missing from Genesis 3:8 is the presence of clouds. According to McKenzie, clouds are "an almost universal element of the theophany." ${ }^{21}$ The obvious reasoning for the lack of clouds in the Genesis passage is that clouds were a unique sign that YHWH gave the Israelites during the Exodus. ${ }^{22}$ Genesis 3:8 may not have every detail of the other storm theophanies we see in the Old Testament, but a vicious thunderstorm in which YHWH visits Adam and Eve in judgment certainly ought to qualify as meeting the minimal qualifications of being a storm theophany, especially when it is seen in the context of being a pre-Sinai storm theophany.

\footnotetext{
${ }^{16}$ Grundke, A Tempest in a Teapot?, 549.

17 Ibid.

${ }^{18}$ Exod 15:7-10; 19:16, 19; Deut 33:26-29; Ezek 1:4; Hab 3:8, 11; Psa 18, 29, 50, 77, 83, 97, 104, 144

19 J.L. McKenzie, "Aspects of Old Testament Thought" The Jerome Biblical Commentary (Englewood Cliffs: Prentice-Hall, 1968), 2:746.

${ }^{20}$ M.F. Rooker, "Theophany," DOTP, 860.

${ }^{21}$ McKenzie, "Cloud," DOB, 145

22 "The first Pentateuchal reference to the cloud occurs as Israel sets out from Egypt (Ex. 13:21-22)." J.E. Hartley, "Holy and Holiness, Clean and Unclean," DOTP, 422.
} 


\section{Concluding Thoughts}

When both the traditional and proposed new translation are placed side-by-side and examined on their own merit, the traditional interpretation has much less grammatical support than the new translation. Moreover, we have example after example of storm theophanies having the same key words and themes that are present in Genesis 3:8. Tradition seems to be the main roadblock for change. Douglas Stuart makes the point that there is more than just a sentimentality at work here. He writes, "large amounts of money and time go into the production of a new Bible version, and extensive sales are required to recoup the investment." ${ }^{23}$ When customers are looking for a new version of the Bible, they almost always turn to a select few favorite passages to see how they are rendered in the new version. If the changes are too dramatic for them, they usually will pass and move onto another version. The proposed change to Genesis 3:8 does not simply change a few words, but it changes the entire mood of the passage. Translators may fear that this significant change would hurt potential sales of their new Bible translation. However, the critics of Niehaus's proposal have failed to show that the traditional reading can stand on its own merit. Now that the semantic evidence has been thoroughly evaluated, it is time to let new translation take root.

Beyond sales numbers, there are also some implications that may make some readers uncomfortable. The idea of God walking in the cool of the day is a peaceful image that is often brought up to remind readers of what was lost in the fall. In fact, the hithpael form of $h l k$ has led interpreters to conclude that this walking in the garden was routine (a possible grammatical feature of the hithpael stem). So not only did YHWH walk with Adam and Eve, but he walked with them daily. If this new translation is correct, YHWH does not come to take his daily stroll with man, but rather comes in a powerful storm to banish Adam and Eve from paradise. The portrayal of YHWH could not be more distinct in the two translations. I challenge readers to take the new translation and read the entire scene in Genesis 3. Every inter-

\footnotetext{
${ }^{23}$ Douglas Stuart, "'Cool of the Day' (Gen 3:8) and "the Way He Should Go' (Prov. 22:6)" BSac 171 (July-September 2014): 261.
}

action with YHWH takes on a new tone. Adam and Eve hide after they hear the thunder and wind of storm, not because they hear the tread of his feet. The way we read YHWH's question, "Where are you?" is wildly different if he is leisurely walking or if thunder and wind are raging as he questions them. Perhaps this gives us a better appreciation for the Mount Sinai storm theophany of Exodus 19 where YHWH appears to Moses and "answered him in thunder" (Ex. 19:19). In Genesis 3 the storm theophany is one of judgement and ends in humanity being banished from the presence of YHWH. In Exodus 19 the storm theophany is how YHWH begins to reveal his new covenant with Israel. This theophany shows the awe-inspiring power of $\mathrm{YHWH}$, who is bringing humanity back to him. In both accounts YHWH speaks to humanity from the storm, but the results of each lead humanity in opposite directions. YHWH is bringing humanity back to paradise, which is why shortly after this scene at Sinai Moses is told to build a tabernacle where YHWH will dwell. The storm theophany in Exodus may be tethered to Genesis 3, which would offer a beautiful reversal of the role of the storm theophany in Israel's salvation history. However, this reversal can only be seen if we read Genesis 3:8 as a storm theophany. 